In his excellent introductory essay, Mayer not only discusses the theatrical history, nature, and function of the plays, but also their ideological significance both in Britain and America. He sees them as a response to many of the cultural and social anxieties of the age: the crisis of religious faith, the rise of feminism, the emergence of class conflict, fear of mass immigration, anxiety about the future of the Empire. He also traces the close link between the stage and the nascent Hollywood film industry, making it clear that it is impossible fully to appreciate the latter without reference to the former.

Both Mayer and Katherine Preston, who contributes an informative essay on the music of the toga play, make it clear that theatre has to be seen as integral to a common culture, informed by a shared set of images and ideas, with toga plays borrowing their plots from popular novels, their visuals from well-known paintings (AlmaTadema, Leighton), and their music from the works of Gounod, Meyerbeer, and Luigini. This collection is invaluable for anyone seeking to understand and interpret popular drama in the late-Victorian and Edwardian periods as also the links between theatre and cinema.

JEFFREY RICHARDS

\author{
Joel H. Kaplan and Sheila Stowell \\ Theatre and Fashion: \\ Oscar Wilde to the Suffragettes \\ Cambridge University Press, 1994. £30.00. \\ ISBN 0-521-41510-1.
}

This is a wonderfully stimulating book that ranges over the many and diverse relationships between the theatre of the late nineteenth and early twentieth centuries and the worlds of fashion and dress. It examines the plays that deal with the clothing industry (Barker's The Madras House, Hamilton's Diana of Dobson's, Knoblock's My Lady's Dress, Lyttelton's Warp and Woof - and it is a revelation just how many plays there are which deal with this topic - and the ways in which the fashion houses used the popular stage and popular performers to model their designs. It also explores other, less expected areas - for example, in a fascinating chapter on the theatricality of the couturière Lucille's mannequin parades, and another on the theatricality of the entrepreneur, Gordon Selfridge, who supported/ exploited not only the theatre but the women's movement in his Oxford Street store.

The authors show how the concern of feminists and suffragists in the period with the relationship between women and dress was explored theatrically in their public displays and in the plays that were a product of feminist agitation. This is not only a book for theatre historians, but for anyone interested in the larger questions of cultural production and the fashion industry, feminism and the body. It demonstrates very clearly, and with many new insights, the complexity and interrelatedness of theatre and other forms of cultural expression at the fin de siecle.

VIV GARDNER

\section{F. W. J. Hemmings \\ The Theatre Industry \\ in Nineteenth-Century France \\ Cambridge University Press, 1993. 319 p. £35.00. \\ ISBN 0-421-44142-0.}

This detailed and erudite study of nineteenthcentury French theatre is framed by the concept of theatre as an industry. The volume is organized into three parts, corresponding to what the author describes as the main preconditions of a successful modern industry: the audiences (consumers), the performers (workforce), and the playwrights (producers). Hemmings makes use of an extensive range of contemporary literature, journalism, and theatre memorabilia to document hitherto under-researched areas concerning the arrangement of theatregoing in Paris, and, to a lesser extent, in the provinces.

Particularly welcome are chapters concerned with working-class audiences, the salaries and contracts of performers, 'the difficult life of the actress', and the organization of the dramatist's (producer's) work as a profession. The study will be particularly useful to anyone researching this period of theatre history, and to social and cultural historians of nineteenth-century France. Moreover, the accessible style of writing and the attention to theatrical detail make this a highly readable volume.

ELAINE ASTON

\section{Twentieth-Century Theatre}

\section{Christopher Innes}

Avant-Garde Theatre, 1892-1992

London: Routledge, 1993. $261 \mathrm{p}$.

$£ 35$ (hbk), $£ 12.99$ (pbk)

ISBN 0-415-06517-8 (hbk), 0-415-06518-6 (pbk).

'Avant-garde' has always been a vague term for a whole gamut of artistic movements, individuals, styles and concepts. Theories of the avant-garde have been promoted by writers as diverse as Marx, Bakunin, Poggioli, and Bürger, and several historical studies have traced the concept's development in twentieth-century theatre. Innes therefore enters a field where there are many competitors, and I am afraid to say that he does not fare too well in comparison with them. What 